dialysis may not be readily accomplished in some patients who have had recent abdominal surgery, multiple abdominal fistulas, or extreme adhesive peritonitis.

The technique described here provides a good compromise, in that those patients with acute renal failure may undergo early haemodialysis with a shunt. The vasculature which is enlarged by the fast flow of the shunt may then be converted to a fistula which can be used immediately for haemodialysis.

${ }^{1}$ Buselmeier, T J, et al, Surgery, 1973, 73, 512.

2 Buselmeier, T J, et al, ASAIO, 1973, 19, 25.

3 Quinton, W E, Dillard, D, and Scribner, B H, ASAIO, 1960, 6, 104.

4 Brescia, M J, et al, New England Fournal of Medicine, 1966, 278, 89.

5 Kjellstrand, C M, et al, Clinical Nephrology, 1975, 4, 37.

(Accepted 18 May 1977)

University of Minnesota Hospitals, Minneapolis, Minnesota 55455, USA

T J BUSELMEIER, MD, associate professor, medicine and surgery J J RYNASIEWICZ, MD, fellow, department of surgery

R H HOWARD, MD, assistant professor, department of surgery

D E R SUTHERLAND, MD, assistant professor, department of surgery

$T$ D DAVIN, MD, instructor, department of medicine

R L LYNCH, MD, instructor, department of medicine

E H HODSON, MD, fellow, department of medicine

R L SIMMONS, MD, professor of surgery and microbiology

J S NAJARIAN, MD, professor and chairman, department of surgery

C M KJELLSTRAND, MD, professor of medicine and surgery

\section{Early antenatal diagnosis of small open spina bifida lesions}

The measurement of $\alpha$-fetoprotein $(\alpha-F P)$ in amniotic fluid is generally a reliable technique for the early antenatal diagnosis of neural tube defects. ${ }^{1}$ It may, however, present difficulties if the fetus has only a small open spina bifida. ${ }^{2}$ We have produced evidence that a careful examination of the morphology of the amniotic fluid cells, particularly those cells that adhere rapidly to glass or plastic surfaces in culture, can help in making such diagnoses. ${ }^{3}$ We report here two cases that illustrate this point.

\section{Case 1}

A 24-year-old mother, para $0+1$, with no history of affected children had three sequential $\alpha$-FP values above the 95 th percentile of the normal range (see table). Amniocentesis at 19 weeks gave an amniotic fluid $\alpha$-FP concentration of $32.8 \mathrm{mg} / 1$. The total cell count was $50 \times 10^{6} / 1 ; 25.3 \times 10^{6} / 1$ were viable. There was no blood cell contamination. Nine per cent of the viable cells were adherent to glass after 20 hours' incubation and all these cells had an abnormal morphology. ${ }^{3}$ The differential cell count showed that $49 \%$ of adherent cells were large vacuolated cells, $14 \%$ were long bipolar cells, and $9 \%$ had multiple filamentous pseudopodia, while $28 \%$ of the nuclei were contained in vacuolated giant multinucleated cells.

A second amniocentesis at 20 weeks gave an $\alpha$-FP level of $24.2 \mathrm{mg} / 1$ The total cell count was $51 \times 10^{6} / 1$, of which $16.4 \times 10^{6} / 1$ were viable. There were $1.3 \times 10^{9}$ red blood cells $/ 1$, of which $20 \%$ were fetal; $6.5 \%$ of the viable cells were adherent, and while all these showed abnormal morphology (nonepithelioid), the long bipolar vacuolated cells were no longer present.

In view of the marginally raised amniotic fluid $\alpha$-FP concentrations the pregnancy was allowed to go to term. The outcome was an infant with a severe lumbar myelocele, who died after four days.

\section{Case 2}

A 26-year-old mother, para $2+0$, with no history of affected children had three sequential $\alpha$-FP values above the 95 th percentile of the normal range. Amniocentesis at 19 weeks, after ultrasound scan, gave an amniotic fluid $\alpha$-FP value of $29.8 \mathrm{mg} / \mathrm{l}$ (see table). The total cell count was $45.4 \times 10^{6} / 1$, of which $18 \times 10^{6} / 1$ were viable. The liquor was contaminated with $2.3<10^{9}$ red blood cells $/ 1$, with $10^{\circ}$ o of fetal origin. Cellular adherence was less than $3 \%$. Most of these cells were small with eccentrically placed nuclei, the remaining few nuclei being present in multinucleate cells which had no vacuolation or cytoplasmic inclusions. These cells are found only where the placenta has been traversed by the needle during amniocentesis. ${ }^{3}$
Serum $\alpha-F P$, amniotic fluid $\alpha-F P$, and proportions of rapidly adherent cells

\begin{tabular}{|c|c|c|c|}
\hline $\begin{array}{l}\text { Gestation } \\
\text { (weeks) }\end{array}$ & $\underset{(\mu \mathrm{g} / 1)}{\operatorname{Serum}} \alpha-\mathrm{FP}$ & 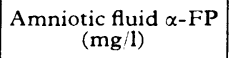 & $\begin{array}{l}\text { Rapidly adherent } \\
\left.\text { cells (" }{ }^{\prime}\right)\end{array}$ \\
\hline \multicolumn{4}{|c|}{ Case 1} \\
\hline $\begin{array}{l}16 \\
18\end{array}$ & $\begin{array}{l}158(85)^{*} \\
118(105)\end{array}$ & & \\
\hline $\begin{array}{l}19 \\
19\end{array}$ & 190 (115) & $32.8(21)^{+}$ & $9 \cdot 0(6) \dagger$ \\
\hline \multicolumn{4}{|c|}{ Case 2} \\
\hline $\begin{array}{l}17 \\
18\end{array}$ & $\begin{array}{l}115(95) \\
170(105)\end{array}$ & & \\
\hline 19 & 125 (115) & $29.8(21)$ & $2 \cdot 1(6)$ \\
\hline 20 & & $22 \cdot 0(17)$ & $<1(6)$ \\
\hline
\end{tabular}

*95th percentile of normal range. +Upper limit of normal.

A second amniocentesis at 20 weeks gave an $\alpha-\mathrm{FP}$ level of $22.0 \mathrm{mg} / \mathrm{l}$. The total cell count was $58 \cdot 3 \cdot 10^{6} / 1$, of which $20 \times 10^{6} / 1$ were viable. There were $2 \cdot 4 \cdot 10^{9}$ red blood cells $/ 1,10 \%$ being fetal. Cellular adherence was less than $1 \%$. There were no cells with abnormal morphology, the very few cells that adhered to the coverslip being epithelioid. In view of the similarity of the $\alpha$-FP concentrations to those in case 1 , however, it was decided to terminate the pregnancy. The fetus had no neural tube defect or any other sign of external or internal abnormality.

\section{Comment}

In each of the two cases described here there were three serum $\alpha$-FP values above the 95 th percentile of the normal range and two amniotic fluid values above the defined upper limit of normal. ${ }^{4}$ In particular the matched amniotic fluid values at 19 and 20 weeks were virtually indistinguishable. The small amount of fetal blood contamination in case 2 , represented by about $2 \times 10^{9}$ fetal red blood cells $/$, could have contributed little to the amniotic fluid $x$-FP concentration.

The results of cellular adherence studies were, however, more discriminating. In case 1 both amniocentesis samples yielded abnormal proportions of rapidly adhering cells with morphology characteristic of a neural tube defect. ${ }^{3}$ In case 2 the first amniocentesis sample showed some adherent cells, but their morphology suggested that the placenta had been traversed rather than that the fetus was abnormal." Examination of the second amniocentesis sample confirmed the suggestion that the fetus was normal, in that fewer than $1 \%$ of adherent cells were seen and these had a normal (epithelioid) morphology.

${ }^{1}$ Brock, D J H, British Medical Bulletin, 1976, 32, 16.

${ }^{2}$ Laurence, K M, et al, Lancet, 1976, 2, 81.

3 Gosden, C, and Brock, D J H, Lancet, 1977, 1, 919.

4 Brock, D J H, Scrimgeour, J B, and Nelson, M M, Clinical Genetics, $1975,7,163$.

(Accepted 18 May 1977)

Department of Human Genetics, University of Edinburgh, Edinburgh

D J H BROCK, BA, PHD, reader in human genetics

MRC Clinical and Population Cytogenetics Unit, Western General Hospital, Edinburgh

CHRISTINE GOSDEN, BSC, PHD, member of scientific staff

\section{Induction of sex hormone binding globulin by phenytoin}

In collecting material for a reference distribution of sex hormone binding globulin (SHBG) concentration, we identified a man who had an SHBG concentration considerably above that of the rest of the male population. After excluding thyroid or hepatic diseases, which are known to raise SHBG concentrations, ${ }^{1}$ the only abnormality remaining which could have possibly caused the high SHBG concentration was epilepsy, for which he was receiving phenytoin. To check the possibility of phenytoin-induced increase in SHBG concentration we decided to study the SHBG concentration in women with epilepsy treated with phenytoin (Difhydan or Fenantoin). 


\section{Patients, methods, and results}

Peripheral venous blood samples were collected from 23 epileptic women of reproductive age who were otherwise healthy and using no other medication than that for epilepsy. Blood was collected at their routine visits at the department of neurology. The plasma SHBG concentration was determined by the method of Rosner ${ }^{2}$ and phenytoin concentrations by the method of Norell et al. ${ }^{3}$

The figure shows the SHBG and the phenytoin concentrations in each subject. The distribution of SHBG in a reference group of 68 fertile, healthy women using intrauterine devices for contraception is indicated by the horizontal lines. Only three of the epileptic women had an SHBG concentration at or below the mean for the reference group. Another five had concentrations within the upper half of the reference range and 15 women had concentrations over two standard deviations above the reference values. A weak correlation $(r-0.40 ; \mathrm{P}<0.05)$ existed between the phenytoin concentration and the plasma SHBG concentration. In a woman who had recently discontinued her phenytoin we found an SHBG concentration of $144 \mathrm{nmol} / 1$ $(41.8 \mu \mathrm{g} / \mathrm{l})$ at a phenytoin concentration of only $18 \mu \mathrm{mol} / 1(4.5 \mu \mathrm{g} / \mathrm{l})$. Four months later, without medication, her SHBG concentration was normal at $35 \mathrm{nmol} / 1(10 \mu \mathrm{g} / \mathrm{l})$.

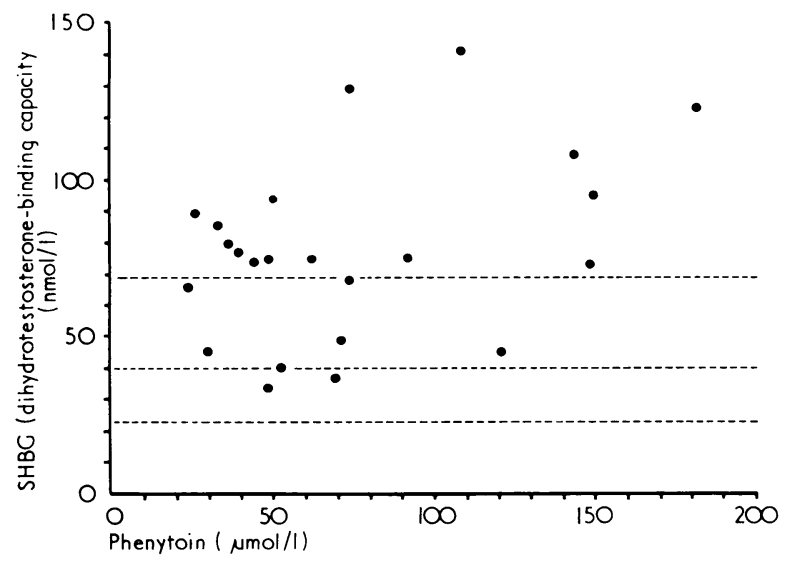

Plasma SHBG and phenytoin concentrations in 23 women treated with phenytoin for epilepsy. Horizontal lines indicate mean and \pm 2 SD of a reference distribution of SHBG in fertile women.

Conversion: SI to traditional units: SHBG: $1 \mathrm{nmol}$ dihydrotestosterone bound $1=0.29 \mu \mathrm{g} / \mathrm{l}$. Phenytoin: $1 \mu \mathrm{mol} / 1=0.25$ $\mu \mathrm{g} / \mathrm{ml}$.

\section{Comment}

To our knowledge no one has reported an effect by antiepileptic drugs on SHBG concentration. Our finding obviously represents another effect of phenytoin on hepatic metabolism, but the further implications can only be hypothetical. It is well known that antiepileptic treatment induces steroid-metabolising enzymes, which alter the effects of both endogenous and exogenous steroids. ${ }^{4}$ Occasional pregnancies in women on oral contraceptives and the lack of therapeutic effect of corticosteroids in epileptics with asthma have both been blamed on this enzyme induction. The induction of SHBG, and possibly of other high-affinity carrier proteins for steroids and other substances, may play a further part in reducing the effects of steroids and possibly vitamins in epileptics by changing the proportion of free and biologically available compound.

Because it is easy to measure, the SHBG concentration may be useful as a measure of enzyme induction in patients treated with antiepileptic medication.

1 Anderson, D C, Clinical Endocrinology, 1974, 3, 69.

${ }^{2}$ Rosner, W, fournal of Clinical Endocrinology and Metabolism, 1972, 34, 983.

3 Norell, E, Liljenberg, G, and Gamstorp, I, European Neurology, 1975, 13, 232.

${ }^{4}$ Richens, A, in Anticonvulsant Drugs and Enzyme Induction, ed A Richens, p 3. Amsterdam, Elsevier, 1976.

(Accepted 31 May 1977)

\section{University Hospital, Uppsala, Sweden}

ARNE VICTOR, MD, physician, department of obstetrics and gynaecology $P$ O LUNDBERG, MD, professor of neurology

ELOF D B JOHANSSON, MD, professor of obstetrics and gynaecology

\section{St Anthony's fire and pseudochronic renal failure}

St Anthony's fire, due to consumption of rye bread contaminated with Claviceps purpurea, was endemic in Europe in the Middle Ages. Most modern cases are iatrogenic, caused by prescribed ergot derivatives. We report here a case of acute renal failure, presenting clinically as chronic renal failure, associated with ergotamine overdose.

\section{Case report}

A 42-year-old housewife presented with a two-week history of headaches, vomiting, debility, confusion, and cold, painful hands. She suffered migraine, and had taken 101 -mg dihydroergotamine tablets daily for two weeks, and 20 tablets the day before admission. She was pale, confused, with pigmented excoriated skin, white nails, but no oedema. Blood pressure was $145 / 75 \mathrm{~mm}$ $\mathrm{Hg}$ and central venous pressure $+3.5 \mathrm{~cm} \mathrm{H}_{2} \mathrm{O}$. Urine output was $3 \mathrm{l} / 24 \mathrm{~h}$, with no history of antecedent oliguria.

Investigations showed: plasma urea $70 \mathrm{mmol} / 1(422 \mathrm{mg} / 100 \mathrm{ml})$, creatinine $2750 \mu \mathrm{mol} / 1(31 \mathrm{mg} / 100 \mathrm{ml})$, sodium $126 \mathrm{mmol}(\mathrm{mEq}) / 1$, potassium $4 \cdot 8$ $\mathrm{mmol}(\mathrm{mEq}) 1$; urinary urea $140 \mathrm{mmol} / 1(843 \mathrm{mg} / 100 \mathrm{ml})$, creatinine 6.8 $\mu \mathrm{mol} / 1(0.08 \mathrm{mg} / 100 \mathrm{ml})$, sodium $48 \mathrm{mmol} / 1$, potassium $25 \mathrm{mmol} / 1$; creatinnine clearance $3 \mathrm{ml} \mathrm{min}$; serum calcium $2.3 \mathrm{mmol} / 1(9.2 \mathrm{mg} / 100 \mathrm{ml})$, phosphate $4.8 \mathrm{mmol} / 1(15 \mathrm{mg} / 100 \mathrm{ml})$, urate $1.02 \mathrm{mmol} / 1(17.2 \mathrm{mg} / 100 \mathrm{ml})$; haemoglobin $8.4 \mathrm{~g} / \mathrm{dl}$, normochromic normocytic film, white cell count $8 \cdot 4: 10^{9} / 1\left(8400 / \mathrm{mm}^{3}\right)$. High-dose intravenous urography (IVU) gave an instant dense persistent nephrogram with normal-sized kidneys but no pyelogram.

She was managed conservatively with fluid and dietary control. Plasma urea fell spontaneously. Urine output remained high, and sodium and potassium supplements were required initially. Three weeks later clinical recovery was complete, plasma urea and creatinine were normal, and creatinine clearance was $54 \mathrm{ml} / \mathrm{min}$. Three months later creatinine clearance was $59 \mathrm{ml} / \mathrm{min}$, renal tubular function was normal, and haemoglobin was 13.4 $\mathrm{g} / \mathrm{dl}$. A repeat IVU was normal.

\section{Comment}

Our patient presented with many features of chronic renal failure ${ }^{1}$ : pigmented excoriated skin, white nails, severe normochromic normocytic anaemia, extremely high plasma creatinine, normal serum calcium, and high urine output (over $2.51 / 24 \mathrm{~h}$ is unusual in established acute renal failure). Her recovery and subsequent investigation led to a diagnosis of acute renal failure, possibly already in the diuretic phase.

Peripheral arteriospasm is a well-recognised complication of ergotamine treatment." Ergotism is usually due to overdose but may occur after small doses in sensitive individuals. ${ }^{3}$ It has followed administration by injection, by suppository, and by mouth. ${ }^{+}$Ergotamine may cause reversible renal arterial spasm, ${ }^{5}$ and patients with ergotism may have a reduced creatinine clearance. ${ }^{35}$ We have found no reports of acute renal failure in ergotism. Prolonged renal arteriospasm, due to ingestion of high doses of ergotamine, may have caused the condition in this case. No other causal factor was apparent. Vomiting late in the illness may have prevented absorption of some ergotamine, allowing recovery of peripheral and renal arteriospasm, but it did not cause significant salt and water depletion.

Our case illustrates the occasional difficulty in differentiating between acute and chronic renal failure. We believe that ergotamine caused this patient's renal failure, and that monitoring of renal function is advisable in individuals taking high doses of ergot alkaloids.

We would like to thank the Director General of Medical Services (RAF) for permission to report this case.

${ }^{1}$ Jones, N, Medicine, 1974, 21, 1289.

2 Glazer, G, Myers, K A, and Davies, E R, Postgraduate Medical fournal, $1966,42,562$.

${ }^{3}$ Cameron, E A, and French, E B, British Medical fournal, 1960, 2, 28.

${ }^{4}$ Byrne-Quinn, E, British Medical fournal, 1964, 2, 552.

5 Fedotin, M S, and Hartman, C, New England fournal of Medicine, 1970, 283, 519.

(Accepted 22 fune 1977)

Renal Unit, Princess Mary's Royal Air Force Hospital, Halton, Buckinghamshire

C D PUSEY, MA, MRCP, specialist in medicine, Flight Lieutenant D J RAINFORD, MB, MRCP, officer in command, Squadron Leade 